\title{
Insecticidal Activities of Phenoxy Analogues of Dihydropipercide*
}

\author{
Masakazu Miyakado, Isamu Nakayama, Ayumu Inoue, \\ Makoto Hatakoshi and Nobuo OHNo \\ Pesticides Research Laboratory, Takarazuka Research Center, \\ Sumitomo Chemical Co., Ltd., Takatsukasa, Takarazuka 665, Japan
}

(Received July 19, 1984)

\begin{abstract}
In this series of communications, we have reported the isolation of an unsaturated amide, namely dihydropipercide [N-isobutyl-11-(3,4-methylenedioxyphenyl)-(2E, 4E)-2,4-undecadienamide] as well as two structually related amides as insecticidal principles from fruits of Piper nigrum L. This communication describes the structure-insecticidal activity relationships of the phenoxy analogues of dihydropipercide. As a result, $N$-isobutyl-12-(3- $\mathrm{Br}, 3-\mathrm{Cl}$ or 3- $\mathrm{CF}_{3}$ phenoxy)-(2E, 4E)-2,4-dodecadienamides were selected as the most toxic compounds against Callosobruchus chinensis (adzuki bean weevil, about ten times as toxic as dihydropipercide). These selected amides revealed noticeable toxicities against Chilo suppressalis (rice stem borer), Musca domestica (housefly) and Spodoptera litura (tobacco cutworm). Electro-physiological study of the $3-\mathrm{CF}_{3}$ phenoxy derivative indicated that it acts on the central nerve cord as a neurotoxic principle. The amide caused Periplaneta americana (American cockroach) to knockdown by injection while the amide did not reveal knockdown effect when the same dosage was applied topically.
\end{abstract}

\section{INTRODUCTION}

In the preceding paper, we have described general synthetic methods and insecticidal activities of several amides structurally related to dihydropipercide $\mathbf{2}[N$-isobutyl-11-(3,4-methylenedioxyphenyl) - $(2 E, 4 E)$ - 2,4 - undecadienamide], a novel insecticidal principle from fruits of Piper nigrum L. As a result, $N$-isobutyl-12-(3,4-methylenedioxyphenoxy)-3-methyl-(2E, $4 E)$-2,4-dodecadienamide 3 was selected as a potent insecticidal compound (Fig. 1). ${ }^{1)}$ In this paper, we describe detailed structure-insecticidal activity relationships of the phenoxy analogues of dihydropipercide

* The Piperaceae Amides (Part 7). For Part 6, see Ref. 1).

Presented in part at the 5th International Congress of Pesticide Chemistry (IUPAC, Kyoto, August, 1982). with various substituents on the aromatic ring and molecular size (chain length).

Pellitorine 1, a representative of natural unsaturated $N$-isobutylamides, has been known as a paralyzing insecticidal agent as well as a pungent principle for the human, however its insecticidal mode of action has not been studied in detail until now. In the present paper some preliminary electro-physiological studies of dihydropipercide $\mathbf{2}$ as well as a selected unsaturated amide are also described.

\section{MATERIALS AND METHODS}

\section{Materials}

All products were fully characterized by ${ }^{1} \mathrm{H}$ NMR, IR and mass spectrometries as well as microanalyses where necessary.

\section{$1.1 \mathrm{~N}$-isobutyl-12-(substituted phenoxy)-(2E,} 4E)-2,4-dodecadienamides 10-18

The synthesis of the amides containing 3,4methylenedioxyphenoxy group has been re- 
<smiles>CCCCCC=CC=CC(=O)NCC(C)C</smiles>

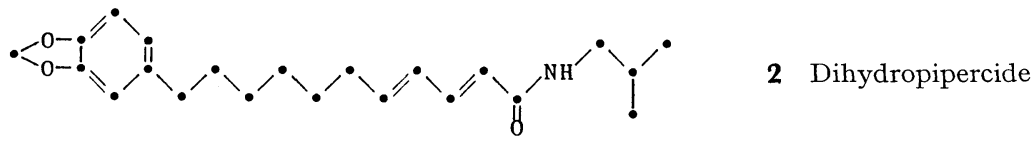<smiles>CC(C=CCCCCCCCO[In]1CC2COC(C2)O1)=CC(=O)NCC(C)C</smiles>

Fig. 1

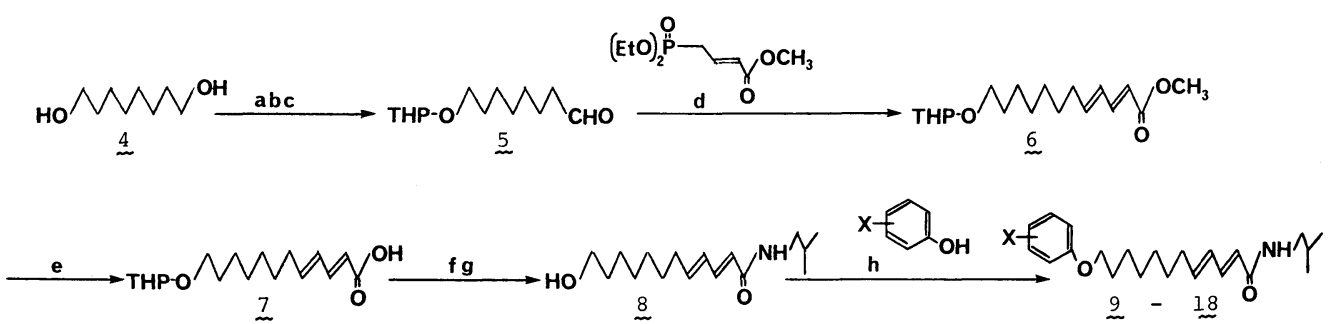

Fig. 2 General synthetic routes of unsaturated amides.

a) THP, $p$-TsOH. b) distillation. c) PCC oxid. d) NaOMe. e) $\mathrm{KOH}-\mathrm{MeOH}$, heat. f) $\left(\mathrm{NPCl}_{2}\right)_{3}$, $\mathrm{Et}_{3} \mathrm{~N}, i-\mathrm{BuNH}_{2}$. g) dil. $\mathrm{HCl}$. h) DCC.

ported in the preceding communication (see Ref. 1)) and the same synthetic route was employed in the present study (see Fig. 2).

1.2 Unsaturated amides with various chain length 19-23

As starting materials for the syntheses of amides 19, 20, 21, 22 and 23, 1,6-hexanediol, 1,7-heptanediol, 1,9-nonanediol, 1,10-decanediol and 1,12-dodecanediol were employed respectively, instead of 1,8-octanediol for $\mathbf{1 6}$. The other synthetic routes were the same as described earlier. ${ }^{1)}$

\subsection{3-Methyl-2E, $4 E$ - and 3-methyl-2Z,4E-} dienamide derivatives 24 and 25

Compounds $\mathbf{2 4}$ and $\mathbf{2 5}$ were synthesized by the same procedure described earlier. ${ }^{1)}$

\subsection{Reference insecticides}

Pyrethrin I was obtained by TLC separation of natural pyrethrins. Purified DDT was obtained in this laboratory by chromatographic separation.

\section{Methods}

\subsection{Measurements of insecticidal activities}

Insecticidal activities of testing compounds against Callosobruchus chinensis (adzuki bean weevil), Chilo suppressalis (rice stem borer), Musca domestica (housefly) and Spodoptera litura (tobacco cutworm) were evaluated by the same procedures described in the preceding paper. ${ }^{1)}$

\subsection{Electro-physiological study on Periplaneta americana (American cockroach)}

Adult male of $P$. americana were used in the experiments. Experimental details have been described in the preceding communication. ${ }^{2)}$

\section{RESULTS AND DISCUSSION}

In the preceding communication, we devided the key molecule (dihydropipercide, 2) into three parts (parts A, B and C, Fig. 3) and the structure-activity relationships at each part revealed the structural requirements of part A (amine moiety) and part B (linear chain moiety) for insecticidal activity. Among the tested amides, compound $\mathbf{3}$ was selected as 


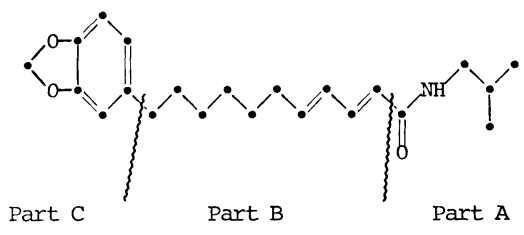

Fig. 3 Dihydropipercide 2.

the most potent insecticidal principle. In this paper, our study was directed to the aromatic substituents of $\mathbf{3}$. Table 1 lists the $\mathrm{LD}_{50}$ values associated with various substituents on the benezene ring in $N$-isobutyl-12-phenoxy-(2E, $4 E)$-2,4-dodecadienamide. Activities of 3,4methylenedioxy analogue 9, natural pyrethrins and fenitrothion are also included in Table 1 for comparison. Compound 9 showed moderate toxicity, however introduction of a methyl, nitro or methoxy substituent at 4position of the phenoxy group resulted in low activities (10, 11 and 12). Halogen atom substituted derivatives at 4-position (13 and 14) were found to show high activities among the 4-substituted phenoxy analogues. 3-Halosub stituted analogues (16 and 17) displayed muc ${ }_{h}^{-}$ higher toxicities than their corresponding 4substituted analogues.

As we expected, 3-trifluoromethyl analogue 18 and 3,4-dichloro analogue 15 also exhibited remarkable insecticidal effect. We should notice that the $\mathrm{LD}_{50}$ values of $\mathbf{1 7}$ and $\mathbf{1 8}$ were smaller than that of fenitrothion.

The marked enhancement of toxicity by introduction of some functions at $\mathrm{C}_{3}$ and/or $\mathrm{C}_{4}$ might be attributed to a retardational effect of these substituents against oxidative metabolism, which is generally observed in the detoxification process for many classes of insecticides. ${ }^{3)}$

As a next step, insecticidal activities of 3chlorophenoxy analogues of various chain length were investigated and the results are summarized in Table 2. The part B with 13 carbon atoms turned out to be optimum length for insecticidal activity (in this case, chain length were counted from the amide carbonyl carbon to the oxygen atom of phenoxy group; the ether oxygen was counted as a methylene).

On the other hand, 3-methyl-(2E, 4E)-2,4dienamide 24 showed almost the same toxicity as that of the parent amide $\mathbf{1 6}$. In the case of 3-chlorophenoxy series, introduction of 3-

Table 1 Insecticidal activities of $N$-isobutyl-12-(substituted phenoxy)-2E,4E-dodecadienamides to adult $C$. chinensis (male).

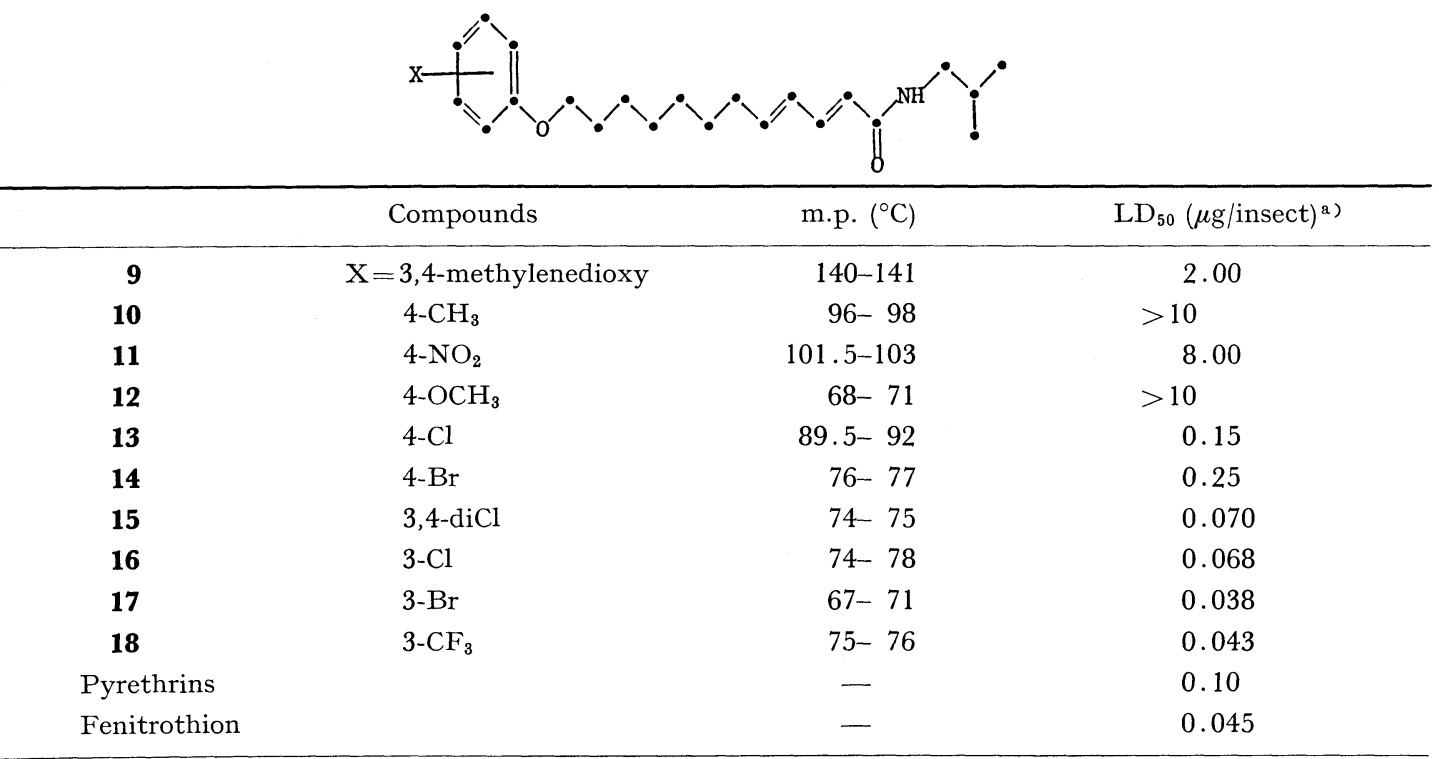

a) Topical application (mortalities were evaluated after $24 \mathrm{hr}$ ). 
Table 2 Insecticidal activities of 3-chlorophenoxy analogues of various chain lengths to adult $C$. chinensis (male).

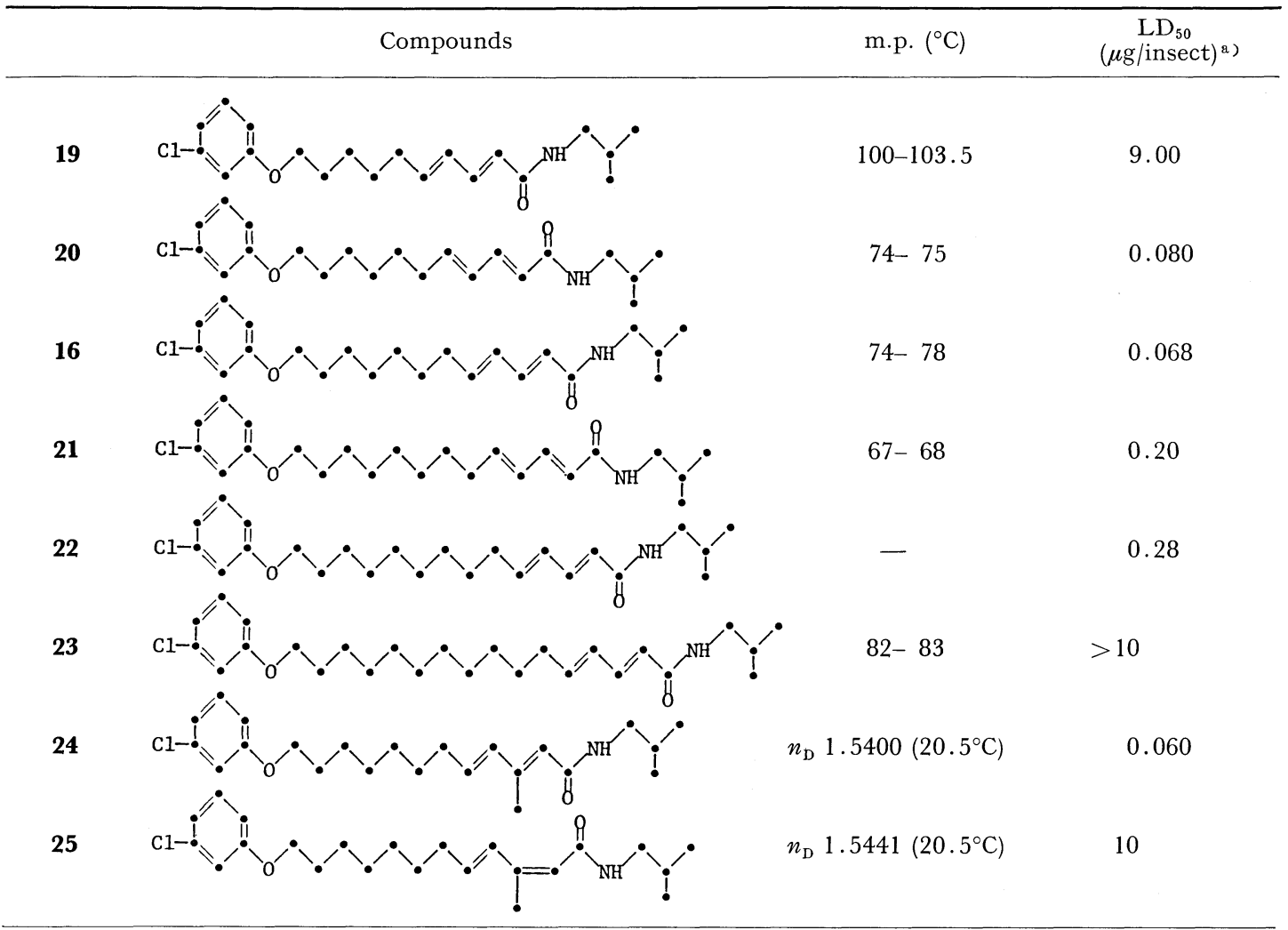

a) see Table 1 .

methyl group did not result in a favourable effect. However, in the case of 3,4-methylenedioxyphenoxy series (see Table 3 in our preceding communication ${ }^{1)}$ ), the 3 -methyl analogue showed noticeable toxicity. 3-Methyl$(2 Z, 4 E)$-analogue 25 showed no activity.

From both of the observations described above and the preceding communication, ${ }^{1)}$ it may be concluded that all parts of the molecule (parts A, B and C) have their optimum structural features as follows:

Part A: Only isobutylamine and its structually related saturated secondary amine analogues are acceptable. Steric limitation is fairly strict.

Part B: Optimum carbon chain length is $\mathrm{C}_{13}$. Terminal benzyl group $\left(\mathrm{Ph}-\mathrm{CH}_{2}-\right)$ can be replaced to phenoxy group ( $\mathrm{Ph}-\mathrm{O}-)$. (2E, $4 E)$-Dienamide moiety is essential. 3-Methyl substituent on the dienamide moiety is ac- ceptable.

Part C: 3,4-Methylenedioxyphenyl group is not essential. 3-Halogen or 4-halogen substituent show good result. Especially, 3-haloanalogue as well as 3-trifluoromethyl analogue exhibit the highest toxicity.

The insecticidal activities of representative synthetic amides against several species of insects were investigated (see Table 3). Compound $\mathbf{1 6}$ showed only poor results against $M$. domestica, however the other three amides $\mathbf{2}$, $\mathbf{1 7}$ and $\mathbf{1 8}$ exhibited complete kill at $500 \mathrm{ppm}$. Compound $\mathbf{2}$ showed no toxicity against $C$. suppressalis. Compounds $\mathbf{2}$ and $\mathbf{1 6}$ showed considerable toxicities against $S$. litura, on the other hand, neither of the two amides $\mathbf{1 7}$ and $\mathbf{1 8}$ revealed activity. In general, the order of insecticidal toxicities against $C$. chinensis were not necessarily consistent with those against the other insect species. From these 
Table 3 Insecticidal activities of some representative amides against several species of insects.

\begin{tabular}{crrr}
\hline \multirow{2}{*}{ Compounds } & \multicolumn{3}{c}{ Activity (kill \%) ${ }^{\mathrm{a})}$} \\
\cline { 2 - 4 } & \multicolumn{1}{c}{$\mathrm{Cs}^{\mathrm{b})}$} & $\mathrm{Md}^{\mathrm{c}}$ & $\mathrm{Sl}^{\mathrm{d}}$ ) \\
\hline $2^{\mathrm{e})}$ & 0 & 100 & 73 \\
$\mathbf{1 6}$ & 100 & 32 & 94 \\
$\mathbf{1 7}$ & 100 & 100 & 0 \\
$\mathbf{1 8}$ & 85 & 100 & 0 \\
\hline
\end{tabular}

a) Experimental methods are given in preceding communication. ${ }^{1)}$

b) Chilo suppressalis.

c) Musca domestica.

d) Spodoptera litura.

e) $\mathrm{LD}_{50}$ on $C$. chinensis was $0.23 \mu \mathrm{g} /$ insect (see Ref. 1)).

observations, it will be still difficult to deduce any definite conclusion on their structureinsecticidal spectra relationships.

Although pellitorine 1, has long been known as an insecticide, its mode of action has not been studied in detail until now. The three amides, pellitorine $\mathbf{1}$, dihydropipercide $\mathbf{2}$ and the selected amide $\mathbf{1 8}$ have a common structure unit $[N$-isobutyl-(2E, $4 E)$-2,4-dienamide moiety] and these three amides exhibited noticeable paralyzing action on several kinds of insects. However, the insecticidal toxicities of the former was far inferior to those of the latter two amides $\mathbf{2}$ and $\mathbf{1 8}$. Now, we describe the electro-physiological study of dihydropipercide $\mathbf{2}$ and the selected amide $\mathbf{1 8}$ on the nervous system of $P$. americana (adult male), in comparison with those of pyrethrin I and DDT (see Table 4). The present two amides induced only repetitive discharge on the central nerve cord, but pyrethrin I induced conduction blockage as well as repetitive discharge. $^{2)}$ On the other hand, DDT revealed no symptom on the central nerve cord within $30 \mathrm{~min}$. From these observations, synthetic amides $\mathbf{2}$ and $\mathbf{1 8}$ seem to act on the nervous system. $^{2}$ This would have some relationship with the results that $\mathbf{2 ,} \mathbf{1 8}$ and pellitorine $\mathbf{1}$ caused knockdown by injection ( $10 \mu \mathrm{g} /$ insect), while these compounds did not reveal knockdown effect when the same dosage was applied topically. ${ }^{4}$

Recent considerable success in the studies on synthetic pyrethroids ${ }^{5)}$ and juvenile hormone mimics ${ }^{6}$ ) have resulted in the development of several thousand-fold or more active compounds as compared with their natural lead compounds, pyrethrins and juvenile hormone I, II and III. The present study has been the first successful modification of natural pepper amides which resulted in about 10 to 170 times increase of insecticidal activity

Table 4 Required time to induce each symptom on the central nerve cord of Periplaneta americana at $10^{-5} \mathrm{M}$ treatment.

\begin{tabular}{|c|c|c|c|}
\hline \multirow{2}{*}{ Compounds } & \multicolumn{3}{|c|}{ Symptom (min) } \\
\hline & IS $^{\text {a) }}$ & $\mathrm{RD}^{\mathrm{b})}$ & $\mathrm{CB}^{\mathrm{c}}$ \\
\hline 2 & 4.0 & 5.0 & $>30$ \\
\hline 18 & 3.0 & 3.5 & $>30$ \\
\hline Pyrethrin I & 0.3 & $0.3-1.0$ & 15 \\
\hline DDT & $>30$ & $>30$ & $>30$ \\
\hline
\end{tabular}

a) Increase of number of spikes. b) Repetitive discharge: both spontaneous and stimulative fireings were observed. c) Conduction blockage: this was determined by cessation of spontaneous activity and lack of response to a stimulus. 
compared to those of dihydropipercide and pellitorine, respectively.

\section{ACKNOWLEDGEMENTS}

We wish to express our thanks to Prof. Toshio Fujita of Kyoto University for his invaluable suggestions. We also wish to thank Dr. Hirosuke Yoshioka of The Institute of Physical and Chemical Research, Japan, for encouragement.

\section{REFERENCES}

1) M. Miyakado, I. Nakayama, A. Inoue, M. Hatakoshi \& N. Ohno: J. Pesticide Sci. 10, 11 (1985)

2) M. Hatakoshi, M. Miyakado, N. Ohno \& I. Nakayama: Appl. Entomol. Zool. 19, 288 (1984)

3) D. M. Soderland, J. R. Sanborn \& P. W. Lee: "Progress in Pesticide Biochemistry and Toxicology," ed. by D. H. Hutson \& T. R. Roberts, Vol. 3, John Wiley \& Sons, Chichester, p. 401, 1983

4) M. Hatakoshi \& M. Miyakado: unpublished results

5) G. G. Briggs, M. Elliott \& N. F. Janes: "Pesticide Chemistry, Human Welfare and the Environment," ed. by J. Miyamoto \& P. C. Kearney, Vol. 2, IUPAC, Pergamon Press, Oxford, p. 157,1983
6) C. A. Henrick: "Insecticide Mode of Action," ed. by J. R. Coats, Academic Press, New York, p. 315,1982

要 約

ジヒドロペパーサイドのフェノキシ類縁体の殺 虫活性*

宮門正和, 中山 勇, 井上 歩 波多腰信, 大野信夫

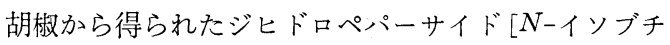
ル-11-(3,4-メチレンジオキシフェニル) - $(2 E, 4 E)-2,4-$ ウンデカジェンアミド]を母核とし，そのフェノキシ類 縁体の構造活性相関の研究を行なった. その結果, アズ キゾウムシに対する活性の優れた化合物として，N-イ ソブチル-12-(3-ブロム, または 3-クロル, または 3-CF フェノキシ)-(2E, $4 E)-2,4-$ ドデカジェンアミドが選択 された.これらアミド類のニカメイチュウ，イエバェお よびハスモンヨトウに対する殺虫活性も調べた.また， ゴキブリの神経を用いた電気生理の研究より，これら一 連の胡椒アミド類は神経に作用する化合物であることが 判明した。

* 胡椒アミドの研究 (第 7 報) 